\title{
Without a Profession: The Politics of Being and Becoming an American Imam
}

\author{
Nancy A. Khalil's Dissertation Abstract
}

Current and recent history has seen an intense struggle over Islam's essence and sources of authority, as well as increasing national tensions over national religion and the idea of an "American Islam." Her work integrates scholarship on authority, theology, and religious freedom to illuminate the imam's contested image in U.S., as well as how the struggle among various stakeholders (e.g., Muslims, politicians, and law enforcement) is shaping the profession. Central to her work with imams is an inquiry into how religion is built, who contributes to a national religious construction, and what are the local and international implications on principles like religious freedom.

Khalil's study is based on over three years of qualitative research in nearly a dozen American cities. Analyzing the results of participant observation, hundreds of interviews, and site visits to aspiring Islamic seminaries, she examines how efforts to shape the profession and mold the figure of these imams are inherently intertwined with various government arms, among them federal law enforcement, state authorizing boards, and foreign policies. She argues that ministry is a necessary path to nationalizing a faith, and that its regulation complicates our understanding of religious freedom. The increasing emergence of Islamic seminaries helps define the borders of other authoritative professions, such as those of a scholar or a jurist, narrowing, by professional elimination, the occupational expectations and the public's understanding of the American imam.

Her dissertation examines the lives of American imams to show how this profession is being formed at the junction of three influences: government regulations impacting ministers, pastoral norms, and the Muslim scholarly tradition to affirm a(n often mutually welcome) latent mosque-state partnership. Beyond the state, normative figurations of religious leadership as clergy also inform and shape the imam's figure to one that is a professional parallel in terms of authority and performance. Examining these contexts highlights the role of the state and bureaucratic procedures in the localized emergence of religious and professional categories like that of American Islam and the American imam. Ultimately, Khalil's work shows that religions are neither shaped in vacuums nor are their leaders immune to the normative processes, forms, and influences present where they try to take root. 